\title{
Az információ elméleteinek evolúciója
}

(részlet „az információ nagyelmélete felé” című tanulmányból.

In: Metaelméleti horizontok. SKI, 2005.)

E tanulmány célja az információ elméleteinek áttekintése a 21. századig. A szerző az információelmélet-alkotás fejlődéstörténetét egyfajta szubjektív szemszögből bemutatva megállapítja, hogy a mai helyzetre a gyenge tudományosság és az erős gyakorlati (piaci) intézményesülés jellemző. A tanulmány a következő témákat tárgyalja: Az információtudományos modellezés és az alkalmazott modellalkotó gondolkodás piaci érvényesülése; az információtudomány történetének nagyepizódjai; az információelméletek és érintőelméleteik, továbbá más tudományelméletek információs érintőelméletei; az információs metaelméletek; az információtudomány egyesített elméletével kapcsolatos kutatások. A gondolatmenetet a tudomány metainformációs piramisának bemutatása zárja le.

\section{Szerzői információ:}

\section{Csorba József}

Az Információs Forrástájékoztató Iroda információs tanácsadója és irodavezetôje. Az információs társadalom témaköreivel foglalkozó $I N C O$ és eVilág címú folyóiratok szerkesztốbizottságának tagja, az elóbbi információpolitika rovatának gondozója. Kutatási témái: nemzeti információpolitikák, az állam információs modellje és makrokommunikációs szerkezete, a humán információkezelő készségek és képességek fejlődése, információforrás-tájékoztatás.

Legutóbb megjelent publikációja: Információ és állam. IFTI, 2004.

Így hivatkozzon erre a cikkre:

Csorba József. „Az információ elméleteinek evolúciója”. Információs Társadalom V, 3. szám (2005): 27-46. https://dx.doi.org/10.22503/inftars.V.2005.3.3

A folyóiratban közölt müvek

a Creative Commons Nevezd meg! - Ne add el! - Így add tovább! 4.0

Nemzetközi Licenc feltételeinek megfelelően használhatók. 
Cisorba József

\section{Az információ elméleteinek evolúciója}

(Részlet „Az információ nagyelmélete felé” címú tanulmányból.

In: Metaelméleti horizontok. SKI, 2005.)

Az alkalmazott információtudomány mai elméleti újdonságai terén a gyakorlati (piaci) információs ismeretek igen gyors ütemú és a hivatalos vagy hagyományos tudományt kikerüló konverziója folyik: naponta új információs csomópontok jelennek meg és új küszöbértékek születnek. Ezek egyfelól új nagyságrendekre, dimenziókra és az azokból következő szembesítésekre, másfelól pedig a tudástermelés és a tudásvesztés új problémáira világítanak rá. Az új típusú tudástermelés és a vele egyidejúleg folyó tudásvesztés egyaránt súlyos gondokat okoz, s ez a társadalom alkalmazkodási válságát, az egyén információkezelési képességének és készségeinek tökéletlenségét bizonyítja. Az emberi információkezelési képességek és a tudás evolúciós küszöbének elve kapcsán beszélni kell arról, hogy ez a problémaegyüttes miként jelenik meg az információ észlelését, megértését, feldolgozását és mobilizálhatóságát biztosító információs kapacitások keretei között.

E kérdéskör anekdotikus próbája az, hogy konkrét tudásunk a megnövekedett hatalmas ismeretanyag közepette mennyire viszonylagos, vagyis mihez képest, milyen alapon teszünk különféle becsléseket. Például az újabb biológiai információs kutatások eredményeként kiderült, hogy az élesztố 6300 gént tartalmaz - ezt az értéket elốzóleg háromszorosan túlbecsültük. Ehhez mérten azt gondoltuk, hogy az embernek legalább 100 ezres nagyságrendú génállománya lehet, de ebból csak mintegy 30 ezret találtak meg. Ez azért elképesztô fejlemény, mert egy sokkal súlyosabb gondra, a hálózatba rendezôdés komplexitásának nagyobb jelentôségére világít rá. Az olyan típusú kijelentésekról, melyek szerint „a 20. század a fizika évszázada volt, a 21. század pedig a biológia évszázada lesz", bebizonyosodott, hogy - mindent összevéve - 20. századi tudást tükröznek. Vannak olyan becslések is, amelyek bizonyos számítások alapján azt állítják, hogy az emberben zajló információs folyamatok, a tudatos és a tudattalan reakciók (például a nyelvhasználat vagy az információvezérelt akaratlagos motorikus mozgások, illetve az emberi szervek információvezérelt funkciói, a hormonrendszerek múködése) együttvéve naponta $3 \times 10^{24}$ bitnyi információ továbbítását jelentik, s ez több mint egymilliószorosa a harmadik millennium küszöbéig az emberiség által összegyújtött (a világ valamennyi könyvtárában tárolt) összes tudás információtartalmának. A korábbiakban mondottakra utalva tehát nem is jó arra gondolni, hogy esetleg megint nagyságrendi tévedésben vagyunk.

Az információval kapcsolatos mennyiségi és minôségi tévedéseink kapcsán érdemes megemlíteni, hogy az információ sokoldalú megközelítései között új irányt jelent az érzelmi jelleg figyelembevétele. Ez az eredeti megfontolás igen messze vezet, egészen az ember arra irányuló képességeinek a gyökeréig, hogy környezetéhez - és így az információhoz is - háromféleképpen viszonyul: az ösztönök, az érzelmek és az értelem szintjén. Ezzel a legegyszerúbb módon magyarázhatjuk meg azt, hogy képesek va- 
gyunk egyidejúleg információtermelô, -észlelố és -befogadó lényként viselkedni. (1. ábra)

\section{Információelméletek a 21. században}

Az új és még újabb osztályozási kísérletek között mostanában kezd megszilárdulni annak a különösen összetett tipológiának az alkalmazása, ami már elsôsorban az intellektuális információkezelési képességek és készségek szempontjából rendszerez, vagyis információ-elméletekrốl (information theories), információs ismeretelméletekról (knowledge theories), tudáselméletekról (intelligence theories), valamint az információs készségek elméleteiról (information management theories) beszél. Ennek az osztályozásnak a felépítését tekintve számolni kell a következókkel.

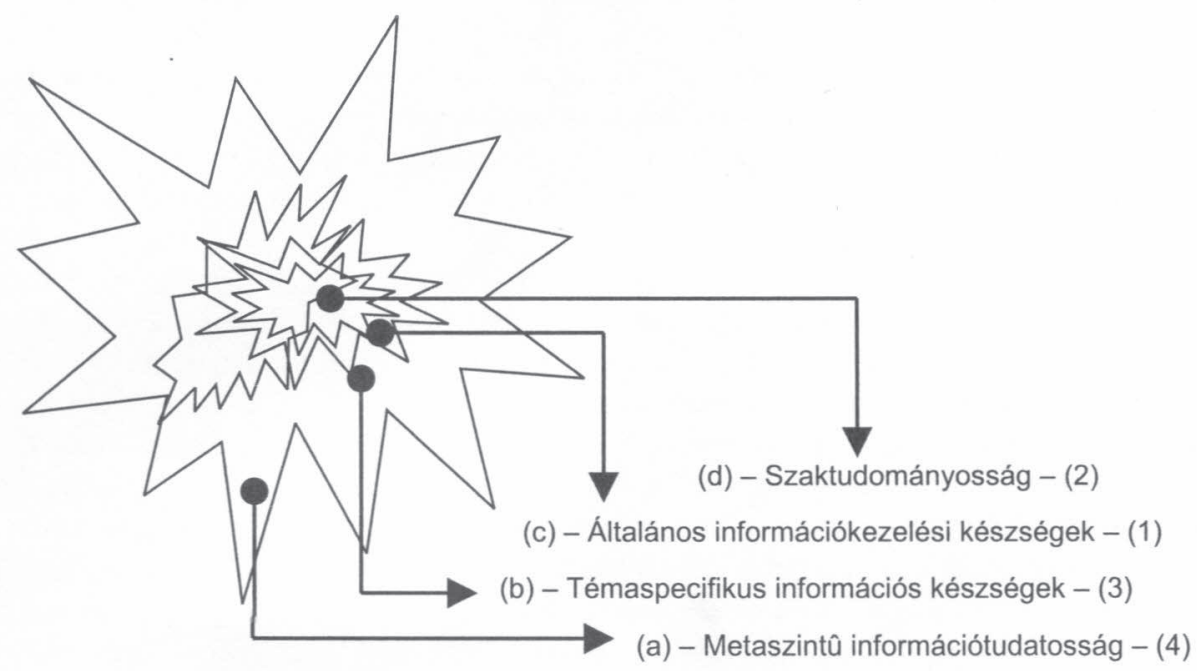

1. ábra. Az információs képességek, az információs készségek és jártasságok, az oktathatóság és a piaci kereslet szerinti tudásértékelés szemléletének ábrázolása. (A betúk és a számok az „információ-ismeret-tudás" logikai út fejlódési folyamatának nem immanens voltát jelzik.)

Az információtudomány fejlődése során az 1970-es és 1980-as években a transzdiszciplinaritás szellemében folytatott amerikai kutatások eredményeként igen széles körú és alaposan dokumentált elméletalkotás történt. Az információfilozófia formálódásának tanulságaként a megfigyelés (információk, tények, adatok, jelenségek rögzítése), a módszertan (modellezés, technikák és megközelítések konceptualizálása), az elméletgyártás (elôfeltevések, magyarázatok, paradigmatizálás) széles körú terjedése, a szintézisre való törekvés, az egységes szemlélet igénye és egy nagytudomány létrehozására való törekvés egyidejúleg van jelen az elméleti és az alkalmazott tudományos gondolkodásban. Az ekkor született tanulmányokban - önállóan vagy együttesen és egyidejúleg, jellemzố módon „érintkezô tudományterületek” címen - elméleti és alkalmazott 
tudományként egyaránt információtudományként jelenik meg a könyvtártudomány, a számítógéptudomány és a kognitív tudomány. Ezt a hagyományos vonulatot kiegészíti az amerikai pszichológiai ismeretelméleti iskola ilyen irányú érdeklődése, a mesterséges intelligenciával kapcsolatos kutatás és a kommunikációtudomány előretörése. Az amerikai és európai filozófiai ismeretelméleti munkákban a „mind science”, a „quantum theory”, az „AI”, valamint a „complexity theory” mezők szerepelnek jellemzóen. A tartalmat és a jelentést kutató európai (vagy kontinentális) és a magyar ismeretelméleti iskola modelljében mindezek mellett a kognitív tudomány, általában a tudatfilozófia, a biológia, a mesterséges intelligencia elmélete, az evolúciós rendszerelmélet, a pszichológia, a számítástechnika, a nyelvészet, az etológia, a percepcióelmélet és a matematika is fontos szerephez jut (Pléh, 1994, 1998). ${ }^{1}$

\section{Az elméletalkotás fejlődéstörténetéből}

A tudományos élet utóbbi évtizedeiben tapasztalt gyenge intézményesülés, vagyis az elméletgyártás robbanásszerú megsokszorozódása és a tudományos megszilárdulás (kidolgozottság, elméleti és tapasztalati megalapozottság, kritika) visszamaradása miatt mindenki keresi a biztos pontokat. A filozófiai ismeretelméleti megközelítés magjaként az amerikai példában a „computation turn” (Information and Computation Sciences, ICS), valamint az ,information turn” (Digital Information and Communication Technologies, DICT) ismeret- és tudáskörei közötti váltás volt a meghatározó. A körülbelül 1930 és 1990 között lezajlott fejlődés teljes történetét az információelmélet, a rendszerelmélet, a kibernetika, a mesterséges intelligencia elmélete, a számítógéptudomány és a komplexitás-elmélet fogalmainak, diszciplínáinak és részdiszciplínáinak a keretei között tárgyalják (Sloman, 1978). ${ }^{2}$

A fejlődéstörténet sajátos jellemzốje a gyenge tudományosság és az erôs piaci intézményesülés, ami szerintünk az információs társadalom paradigmáján belül meghatározó, újszerú mérés és minősítés, valamint a közjóként felfogott információ kapcsán különösen szemléletesen magyarázható (lásd 2. ábra). Ebben a gondolatmenetben, csak az átadás szintjeinek és nem a tartalmának (például az információ közjóként való felfogásának) a magyarázatában ugyanis az információ feldolgozása (birtokbavétele) és hasznosítása (értékelése és értékesítése) először is a tartalom, majd a termék, majd a szolgáltatás, végül pedig a készség birtoklását és értékesítését jelenti. A gyakorlatban végbement fejlődés során azonban mindez egészen más sorrendben történt. A mindennapi életben ugyanis először az információszolgáltatás intézményesült, gondoljunk a klasszikus könyvtári szolgáltatásokra. Ezt követôen jelent meg az információ mint termék, melynek feldolgozottsági foka vagy hozzáadott értéktartalma sokáig nem volt elég magas, és a piacot hosszú idốn át a még ma is uralkodó infomedier termékek és szolgáltatások jellemezték. Az 1990-es években kezdett jellemzốvé válni a tartalom, s annak kapcsán a

${ }^{1}$ Lásd Pléh Csaba (1998): Bevezetés a megismeréstudományba. Typotex, valamint Kognití tudomány (szerk, 1996) c. múveit.

${ }^{2}$ Lásd Sloman, A. (1978): The Computer Revolution in Philosophy, továbbá az általa hivatkozott szerzók (Simon, 1962; A. R. Anderson, 1964; Hayes, 1969; Pagels, 1988; Burkholder, 1992; McCarthy, 1995) munkáit. 
minőségi, szintetizált információ, ami igen jelentôs hozzáadott értéktartalommal bír. Csak ezek után lehet beszélni a fizikai és a szellemi információ feldolgozásával kapcsolatos készségek fontosságáról, az információs múveltségrốl: ez utóbbiak már a 21. századi kor információigényességét jelzik.

(3) szolgáltatás - (a)

(2) termék - (b)

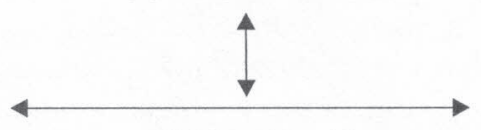

(1) tartalom - (c)

(4) készség - (d)

2. ábra. A mérés és minősítés, az információ közjó jellegének modellezése

Nem feledhetô körülmény továbbá az sem, hogy a gyakorlatvezérelt intézményesülésben mennyire meghatározóak az információrobbanás terepei. Az első és legfontosabb terep a tudomány professzionalizálódása, ami többek között nyilvánvalóvá teszi, hogy a tudomány birodalmában intézményes verseny folyik. A második terep a K+F tevékenység jelentôs bơvülése, ami egyben a növekedés mérésének és minốsítésének a területén is innovációkat gerjeszt. A harmadik terep a felsőoktatás expanziója, amivel együtt megjelenik a szelekció és a túltermelés, az információs múveltség és az információs képességek és készségek mentén történő kiválasztódás.

\section{Nyugati és keleti tudomány}

Az információtudomány fejlődésének menetében a modellalkotó gondolkodás, az információtudatos szemlélet alapja játssza a logikai vezetố szerepet. A modellalkotó gondolkodás egyben az elméletalkotás és a metaelméletek osztódásának alapja is. Az információelméletek egységes tudománnyá fejlődésének jellemzô vonulata az 1960-as évek jeltudományos konjunktúrájának sajátos útjait képviseló információtudomány és az informatika találkozása. Nem kívánok kitérni arra a különleges viszonyra, ami az információ(tudomány) és az informatika(tudomány) kapcsolódását jellemzi. Számomra itt és most ez a viszony olyan, mint a technika és a technológia kapcsolata. Ami igazán érdekes benne, az elsốsorban a francia és az orosz informatikai-infornomikai iskola kifutása, pontosabban az, ahogyan ez a két iskola építkezik. Ebból a szempontból fontos a modell mint az ismerethalmazok lehetséges rendezési, magyarázási módja (Stoff, 1964). ${ }^{3}$ A modell információt szolgáltat tárgyáról, és bár nem azonos az „elmélettel”, a jól megfogalmazott (strukturált, konceptualizált) modellból lehet elméletet gyártani. A modell mint tudományos absztrakció az információfeldolgozásban az analízis-szintézis-absztrakció szintézislépcsók alapja. A modell mint elốzmény az információtudatos vagy -tudományos modellezésben, következményként pedig a szaktudományos összegezésben és a szintézisben alapvető fontosságú.

\footnotetext{
${ }^{3}$ Stoff, V. (1973): Modell és filozófia címú múvében ismertetett érvelése nyomán.
} 
Az információtudatos vagy -tudományos modellezés gyakorlati problémáiban a korai évtizedeket (1940-1960) a számalapú vagy számosító modellek, például az adatalapú, tényekre épülő összegezések és szembesítések uralták. Ezek nyomán olyan megdöbbentő eredmények születtek, mint például a kanadai erdók múholdas feltérképezése, melynek eredményeképpen kiderült, hogy az erdőterület 600 négyzetkilométerrel nagyobb, mint ami a hivatalos térképeken szerepel. Ilyen releváló példák továbbá a magyar térképek torzításai (hamisításai), vagy „a magyar ember lábnyomát” úgy beállító nézetek, melyek szerint olyan „lelakott” az ország, mintha 30 millióan élnénk benne. Hasonló példa a magyar adósságképlet számítása az információdoboz-modell alapján, miszerint a magyar állam forráshiánya 2004-ben 10 millió lakossal számolva már mintegy 55-60 ezer milliárd forint volt.

Az 1970-es és 80-as években érdekesség szinten a szöveghalmaz típusú modellek uralkodtak (a valóságban is, de ezt csak kevesek ismerték fel - jó példa erre az idegen államok kutatási tevékenységének felderítése a nyomtatott és az elektronikus irodalom figyelésével). Az 1980-as és 90-es évtizedekben az információkutatás döntően a statisztikai adatok információtartalmának gazdagításával, például a foglalkoztatási adatoknak tercier források, többek között az újságokban közölt álláshirdetések figyelése útján történt pontosításával foglalkozott. A 20. század utolsó évtizedeiben, amikor a korábbi egyvagy kétdimenziós számosítások tökéletlenségének felismerése széles körben nyilvánvalóvá vált, már a mérés és a minősítés átalakításának (finomításának, illetve drasztikus megváltoztatásának) kényszere került eloótérbe. Az analitikus és a holisztikus látásmód vegyítésével megjelent a többdimenziós statisztikai leképezés (például GNP + GDP + GNI = GWI) utáni információkezelés. Mindent összevéve azt mondhatnánk, hogy az új tudományos felismerések ma az új szemantikai ismeretelméleti modellekben - a természettudományi egyenletek és a matematikai-logikai jelrendszerek után - elsôsorban az információtudományos megfigyelések és a szöveghalmazokat számosító kísérletek adatainak tömegéból, másod- és harmadelemzések nyomán születnek.

\section{Az információtudományos modellezés alapjairól}

Az információtudományos modellezés a természetes és mesterséges szöveg- és jelhalmazokból álló ismerettárak képzéséhez szükséges strukturálás eszköze. A legjellemzóbb, legtöbbet idézett gyakorlati példa e téren, az információmennyiség és a feldolgozási készség (tudás + kapacitás) modellezésében a globálisan évi 10 millió könyv típusú szerzói termék születése a világban. (Ez az 1990-es évek termésének átlagoló számosítása). Az évi 10 millió könyv jellegú szerzói terméknek mintegy 70\%-a a gépvagy kódkönyv, a meta jellegú-nyelvezetú mesterséges jel- és szövegstruktúra, és csak $30 \%$ a közvetlen emberi fogyasztásra alkalmas, kulturális, múvészeti, szórakoztató stb. múvek aránya. Az információtudományos modellezés terepein, a szemantikai interpretációban a tartalom- és/vagy jelentéselmélettel formalizált, strukturált információhalmazok, a szemiotikai interpretációban pedig a jelelmélettel nem formalizált, nyers információhalmazok sokasága, a nagytudomány szabályai szerint hivatalosan nem intézményesült információs tudás jött létre. Ennek konceptualizálása nincs készen, vagyis nincs egyezményes, letisztult, általánosan elfogadott fogalomhasználat, s ez nehe- 
zíti a tudományos intézményesülést. Vannak kommunikációs modellek az ismeretelméleti kutatásokban, vagyis létezik átjárás a tudományterületek között, de ez sem könnyíti meg a tudásegész típusú intézményesülést.

Ellenben ma, az információelméletek szaporodása nyomán szinte minden diszciplínának van saját információelmélete. Másként fogalmazva: a szép számú és egyre szaporodó metaelméletek mint a tudományok információelméletei is értékelhetók vagy legalábbis az ôsi kínai enciklopédiakészítés módjára - valamilyen logikai kategóriába, osztályba rendezhetốk. A lassú intézményesülés és a gyors piaci tudáskonvertálás egyik jellegzetessége 2004-ben az, hogy még mindig a 20-30 évvel korábbi jelen- és jövő́tudással kapcsolatos ismeretek alapján készítünk társadalmi, gazdasági stb. programokat, mégpedig azért, mert a tudományos intézményesülés (a katedráról átadott tudás) már évtizedekkel van elmaradva az alkalmazott információelméletek és a gyakorlati információkezelés nyomán kialakult, alkalmazott, de „hivatalos tudássá” nem rendezett ismeretektól. Az elméletgyártásban, illetve a paradigmatizálásban az információdobozmodell alkalmazása jelzi ezt, olyan példákkal, mint az „államrendszer-szoftver” használata (56 változós modell, melyben az utolsó 10 változót a munkásokkal, alkalmazottakkal egyeztetve határozzák meg a következó évi költségvetés tárgyalásakor), vagy a trend-és tendenciakutatások alkalmazása az állandó változások megjelenítésére. Ez utóbbiak eszközei a konjunktúrakutatás (a ciklusok modellezése), a prognosztika (az elórejelzések modellezése) és a futurológia (a jövốképek modellezése) - ezeknek a technikáknak az alkalmazása a hivatalos tudomány talaján áll, de információtudatos értelmezésük, magyarázásuk már (vagy még) jobbára metaelméleti szinten történik.

A fentiekben leírtakhoz szükséges információtudományos (fizikai és intellektuális) készségek fejlődése az 1940-es években, a világháború során kibontakozó technikai-technológiai forradalommal kezdődik. Egyfelól a számítástechnika tudománya és a rendszerelmélet (mint információrendszerezô készségek), a menedzsment-elméletek (mint információalkalmazó készségek és képességek), az intellektuális információkezelés (mint az információ észlelését, felismerését, rögzítését, értelmezését, visszacsatolását, visszakeresését és mobilizálását lehetôvé tevő emberi képességek) fejlôdése egyre inkább igényli a rendezettséget (innen az információtudomány kritikai rendszerszemléletének lényege); másfelól a növekvő információkezelési igényból fakadó invenciózus egyéni magatartás, illetve az innovatív közösségi (vállalati) viselkedés kényszere gyorsítja az elméleti és a nyelvi metaelméleti, magyarázó-értelmezố készségek fejlôdését.

Az információtudományos fejlődés az információtudatos viselkedés és a modellalkotó gondolkodás révén, a rendezetlenségek (kvázikaotikus állapotok) strukturált ismeretekké alakításával próbálja behozni az elmélet elmaradását a gyakorlattól. Így születnek sorra az elméletgyártás és a kvázi kezelés szabványai: az információs szabványok (a tudománnyá szilárdult jeltovábbító protokollok vagy a mindmáig a metatartományba tartozó jelentéskezelő protokollok) és a kommunikációs szabványok (képi és szövegszabványok, webszabványok stb).

Az elôzőekból következő fejlemény, hogy az „ember és információ” fejlődéstengely modellezésében a tengely súlypontja is eltolódik a mind többet és mind kiérleltebben magyarázott fejlődés irányában. A súlypont már régen nem középen van, vagyis az ember információfeldolgozási készségeinek fejlődéstengelyén a múlt és a jelen (a ka- 
tedrán átadható tudás) a rövidebb tengelyszáron van, és mind hosszabb lesz, mind messzebbre nyúlik a tengely metaelméleti-metatudás szára. (3. ábra)

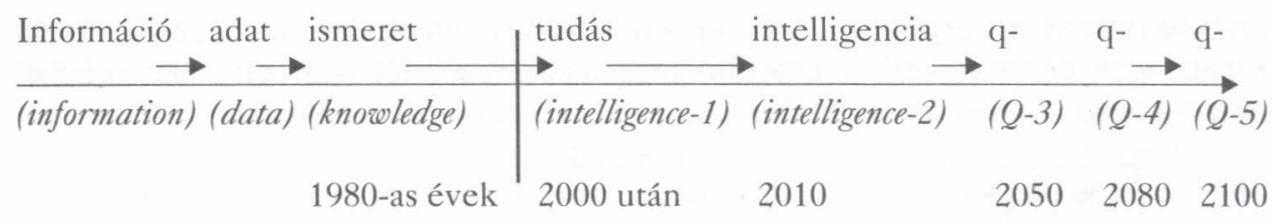

3. ábra. Az információfeldolgozás fejlôdése a szuperintelligenciák irányában: a fizikai és intellektuális készségek hozzáadott értéktartalmának modellezése

Ma a tengely súlypontja az intézményesült (a katedráról átadható) tudás szempontjából, illetve a hagyományos tudás keretei között az ismeret (knowledge) és a tudás mint bázisintelligencia (intelligence-1) között van. Az új elméleti vagy metatudományos keretek között viszont a súlypont az intelligencia mint tudásegész (intelligence-2), vagy merészebb elméleti horizontokon már a Q-2 és Q-3 szuperintelligencia tudástartományoknál van. Ezen utóbbi információs múveltségtartományok mint tudásszférák (óvatos) megvilágítása a következő évtizedek feladata lesz, bár már a jelenben is léteznek.

\section{Az információtudomány történetének nagyepizódjaiból}

A fejlődéstörténet magyarázatában fontos a hagyományos tudományosság intézményi keretei között meglévő elméleti sarokkövek vagy forráspontok megjelölése is. Annál is inkább, mert itt a nagytudományban fényes csillagokat felvonultató magyar tudomány egyik jeles képviselójéról is szó van. Az információtudatos viselkedés és az információmérnökség megjelenése között ezredévnyi fejlődés súrúsödött össze néhány évtizedre. Az ember és az információ viszonyának fejlődéstörténetében a számosítás a legegyértelmúbb és ma mindenki által elismerten minósített „haladás”, benne a mennyiségi felismerések (és a vonatkozó konceptualizálás), az azokkal való szembesítés (a problémafelismerés), valamint a számokkal megalapozott ismeretgenerálás (a strukturálás) nagyepizódjaival. Sokak szerint az 1940-es és 50-es évek után, az 1960-as és 70-es években szinte semmi más nem történt, mint hogy birtokba vettük az előzố évtizedekben létrehozott ismereteket, és megfelelő nyelvezeteket generáltunk hozzájuk. 1980 után azonban már sokkal többrốl van szó.

Amikor már nem a „technológiai forradalomról”, hanem inkább az intellektuális információfeldolgozási készségek fejlódéséról beszélünk, elérkeztünk a tartalom-és jelentéskutatás magasabb szférájába, ahol az 1970-es években történt valami, amit Kemény János „jelentős evolúciós változásnak” minősít (Kemény, 1959). Kemény szerint az ember úton van afelé, hogy jobban ki tudja használni az „információban bôvelkedő világot”. Vagyis létezik egy mérföldkő, s ez Kemény megfogalmazásában az információ-

${ }^{4}$ Lásd Kemény, J. (1959): A Philosopher looks at Science, továbbá Tarski, A. (1956): Logic, semantics, metamathematics, valamint Chomsky, N. (1956): The Logical Structure of Linguistic Theory c. munkáit. 
feldolgozás evolúciója (4. ábra). Innentól kell számítani, hogy miként halad az információtudomány intézményesülése, miként halad ezzel párhuzamosan a hagyományos tudomány(ok) és az információtudomány érintkezése és kölcsönös megtermékenyülése, továbbá miként lesz egyre erôsebb az egyetlen nagyelmélet vagy a tudásegész felé való haladás igénye, s innentốl beszélhetünk megalapozottan arról, hogy a fejlődés az információtudomány mint a metaelméletek metaelmélete irányában halad.

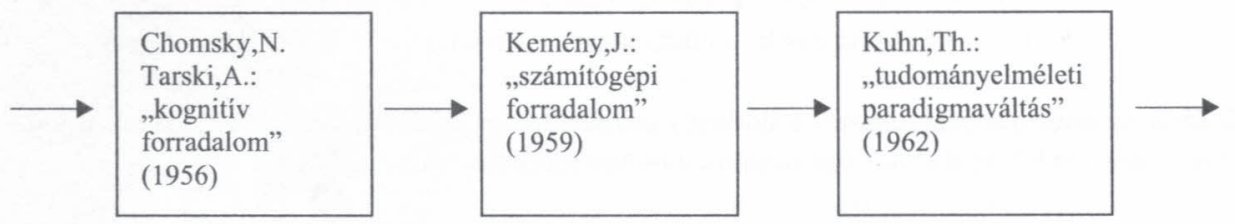

4. ábra. Az információkezelés evolúciós küszöbe szemlélet alapjainak magyarázata, s akikhez köthetố

Az információtudomány tudományelmélete azonban ma még különféle iskolák és irányzatok foglya. A területiség elve szerint például információelméletek, érintôelméletek, tudáselméletek logikai vezérelvei mentén próbálják összegezni, az idóbeliség elve alapján pedig az általános, valamint az inter-, multi- és transzdiszciplinaritás fejlődésmenetében társult információelméletek bukkannak fel.

\section{Az információs metaelméletről}

Az információtudomány a könyvtártudomány, valamint a számítás- és számítógép-tudomány jogán ugyan hosszú idốn át gyakran szóba került, de önálló tudományként a nagytudományban nem érvényesült igazán. Ezért azt lehet mondani, hogy az

információtudomány az 1970-es évektôl mint metatudomány építkezett, bár évtizednyi idố alatt a legizgalmasabb tudományterületté vált, és mint segédtudomány vagy alkalmazott társtudomány az 1980-as évektól már a legmagasabb összegekkel támogatott tudományterületek között jelent meg. Mára, amikor az információtudomány a hagyományos keretek között szemlélve reál és egyszersmind humán diszciplínává válik, miután a területiség és az idóbeliség elve szerint a 20. század első felében először egy matematikai-fizikai ôselméleti területre, majd a 20. század második felében egy kognitív mezốelméleti területre szakosodott, s a 21. század elsố felében információmenedzsmentként is jellemezhetố szakterületként már a metaelméletek metaelmélete.

A metaelméleti vagy a paradigmatizáló gondolkodás és az információtudatos viselkedés tárgyalása során nem lehet figyelmen kívül hagyni a Kuhn-féle „dogmatikus” tudományelméleti vitákat (Kuhn, 1962, 1970, 1984), ${ }^{5}$ de esetünkben csak (vagy éppen) azért, mert miközben az információtudományos elméletalkotás szinte kizárólag meta-

${ }^{5}$ Kuhn, T.(1962): Theory change as structure-change: comments on the sneed formalism In ButtsHintikka (eds.) (1976): Historical and Philosophical Dimensions of Logic, Methodology and Philosophy of Science, valamint A tudományos forradalmak szerkezete (1984) címû́ mûvei nyomán. 
elméleti síkon zajlik, a gyakorlatban a paradigmatizálás az információtudatos viselkedés lényegét jelentố modellalkotó gondolkodás révén egyre gazdagabb és egyre gyakorlatiasabb példákkal szolgál. (Igaz, ezeknek a hiányos elméleti megalapozottsága és ebból fakadó vitathatósága sokszor kérdésessé teszi a felhasználhatóságukat). Ebben az összefüggésrendszerben alapvetốnek számít Kuhn paradigmafogalma: Kuhn sokkal nagyobb információtudatosságot árul el kortársainál. Gondolatmenetünk szerint az 1970-es években az információtudomány is elérte a kuhni normális állapotot, de azóta sem sikerült intézményesíteni, vagyis - korábbi kifejezésünkkel élve - a „katedráról oktatható” hivatalos tudomány státusába juttatni. Ugyanakkor az ezredfordulón az információtudomány metaelméleteinek sora körvonalazódik. A korai mennyiségi információelméleti és a nem késóbbi, de mégis utóbbi szemantikai információelméleti vonulat a rendszerelméletekkel (csúcsukon az absztrakt dinamikus rendszerek entrópiaelméletével) ért el valamilyen összegzés szintjére, ahol lehetôvé válik a visszatekintés, az elméletek vitathatósága és magyarázhatósága mellett, majd - a kognitív elméleti vonulaton át - az intelligenciaelmélet területére, ahonnan visszatekintve az 1980-as évek elö́tti fogalmak és módszerek már az információtudomány kókorszakához tartoznak: más megközelítésben ezt a fejlődési szakaszt nevezhetjük az információ mcluhani romantikus korszakának (1. táblázat).

Az információtudomány tudományelmélete lényegében Vannevar Bush-tól indul, aki az Office of Scientific Research and Development igazgatójaként megközelítóleg hatezer amerikai tudós munkáját koordinálta a második világháború tudományversenyében. Bush ekkor - minden körülményt figyelembe véve - „kapuemberként”, integrátor és modellalkotó gondolkodóként a megfeleló helyen lévố megfelelő́ ember volt ahhoz, hogy felvethesse az ember összegezett tudásának mint hatalmas ismerettárnak a mobilizálásával, illetve hatékony, gyors és eredményes hasznosításával kapcsolatos problémák lehetséges megoldását. Bush háborús megbízatása egyszeri, azonnali, csak az eredményt elfogadó feladat volt: a világ egyik legnagyobb országában rendelkezésre álló társadalmi, gazdasági és humán források, valamint az azokkal kapcsolatos információ- és adattömeg kezelését kellett megoldania, bizonyos modellek megalkotásának a segítségével. Bush arra törekedett, hogy tudományos rangra emelje az információval kapcsolatos gyakorlati tudást, miközben „Memex” elnevezésú találmánya az emberi agy véges memóriakapacitásának gépi megnövelését volt hivatott elốsegíteni.

\section{Az információtudomány metaelméleteiről}

A teljesség igénye nélkül, továbbá anélkül, hogy a terület- és korspecifikus rendezettség, a tudományos elózmények és utóéletek bemutatására törekednék, a következôket tartom meghatározónak. Az „információelmélet” címszó alatt az angol nyelvú lexikonok és az amerikai szemináriumok - C. Shannon A kommunikáció matematikai elmélete (Mathematical Theory of Communication) címú, 1948-ban megjelent tanulmánya nyomán - kb. 200 minôsített forrásmunkát sorolnak fel, az information theory, a communication theory, a statistics és a probability theory területei között elhelyezve az útjelzôt. A generalizált Shannon-elmélet - durva általánosítással - az információmatematika hordozója, a mai információrendszerek információs és kommunikációs infrastruktúrája kö- 


\section{$1.1 \mathrm{Az}$ „,információs környezet” kiteljesedése (1950-1980)}

A gyors fejlõdés kora, amit a gyors alkalmazásba vétel és a lassú intézményesülés, továbbá az információelméletek és az azokat érintõ tudományterületek metaelméleti jellegû szaporodása jellemez, miközben a katedráról hirdetett „információtudományosság” évtizedekkel lemarad, az új információtudatosság és az új információérzékenység azonban töretlenül fejlõdik és terjeszkedik. Erre utal a harmadik írásbeliség igényének megjelenése: új nyelvek, új struktúrák (metaelméletek, paradigmák), ismeret- és tudástárak mobilizálása.

\subsubsection{A filozófiai magyarázat terepei (1987-1991):}

(a) holisztikus megközelítés (3)

(b) Gestalt megközelítés (2)

(c) analitikus megközelítés (1)

1.1.2 Az alkalmazott információtudományos magyarázat terepei, az internet információs és kommunikációs infrastruktúrája alapján:

WEB LifeLog ASSIST Project Wikipedia

DATAGRID $\quad$ SUPERGRID PlanetLab-2

\subsection{A mcluhani romantikus információelmélet kora (1940-1990)}

Ez az a korszak, amikor az információs társadalom elméleti paradigmájából átléptünk az információgazdag és információfüggõ társadalmi praxisba, amelyben minden és mindenki a „megfelelõen mûködõ" információs rendszerektõl függ (ideértve a kommunikációs rendszereket is). Ez az állam nélküli és az önszabályozó (civil) információfogyasztás és információgenerálás eszményi korszaka. Az információjogi és az adminisztratív fejlõdés az egyén jogaira összpontosit a közösséggel szemben. A korszakot mint kvázikaotikus rendszerforma az információkereskedelem, valamint az információs gazdaság és az információgazdaság kialakulása és intézményesülése jellemzi.

\subsection{A castellsi informacionalista információelmélet kora (1980-2010)}

Ez az a kor, amikor a létrejövõ újkapitalizmus társadalma a kulturális kódolás birtoklása, illetve a technológiai és az intellektuális információfeldolgozási készségek magasabbrendûsége alapján szegregálódik. A hagyományos szabad versenyes piac korlátozásával bekövetkezik az információgazdaság globalizációja, ugyanakkor megjelenik az állami szabályozás követelése a gazdasági aktorok részérõl (is). A korszakot az információs anarchizmus eluralkodása, a közösségi információvagyon, a közérdekû, közhasznú, közbiztonsági információrendszerek mindennapos veszélyeztetettsége jellemzi. Ennek legfõbb következménye az információ közjó jellegének sérülése: uralkodóvá válik az információ kisajátítására való törekvés; a közösségi információtárak használata, illetve védelme terén állandóan konfrontálódnak az egyéni és a közösségi érdekek. A globalizáció során elodázhatatlanná válik az állam szerepének újragondolása. Ez az új információs tér és rend kialakulásának kora, amit a kormányokat és az államokat nagy mértékben korlátozó kvázikaotikus társadalom hoz létre.

1. táblázat. Az információ korának korszakolása a paradigmatizálás szempontjából 
zötti egyezések és különbségek tárgyalásának megalapozója. ${ }^{6}$ E fốcsapás mentén a tapasztaláson keresztül érlelődő elméletet generáló legfontosabb entitás a digitalizáció az információs társadalom paradigmájában ebból következik az elektronizáció-digitalizáció-informatizáció fejlődésmenet útjának felismerése és minôsítése. ${ }^{7}$ Az információ rögzítése, tárolása és mobilizálása terén bekövetkezett mennyiségi és minôségi ugráshoz vezetô döntô felismerés az volt, hogy az információ leírható számokkal, amelyek különféle állapotokat képeznek le. A digitalizáció (információ)elmélete azonban csupán egy „szürkeállapotú” esemény volt a tudomány fejlődésének folyamatában, bár az alapok egyik legfontosabb téglája lett. Ugyanezen az útvonalon sokkal nagyobb visszhanggal járt egy másik érintốtudományos terület felbukkanása, amely témánk enciklopédistáinál „az entrópia az információ- és kódelméletben” címen található meg. ${ }^{8}$

Egészen más a megközelítés iránya a tanuláselméletek felól, ahonnan az információelmélet a gépi információfeldolgozási vagy a humán kognitivista érintốelméletekhez vezet: a gépek (be)tanításával foglalkozó vezetési elméletekhez, ahol az információelmélet érintốelméletei a programozás megalapozása terén egyfelól a behaviorizmus és a kognitivizmus, másfelól pedig a rendszerelmélet, a kibernetika és a kommunikációelmélet (Chaitin, 1995). ${ }^{9}$

Eddig még senki sem szánta rá magát, hogy a különféle irányú megközelítések között valamilyen rendet vagy rendszert alakítson ki. Az információelméletek kibomlásától az információtudomány megszilárdulásáig terjedô, egyre szélesedố tudományelméleti spektrumot a csupán felületes tájékozódásból leszúrt tapasztalatok összegzése után, a humán és reál kategóriákra való felosztások figyelembevételével a magam részéról a következóképpen látom: Az ôselméletek, a mennyiségi és a szemantikai információelméletek után a rendszerelméleti információelméletek, majd a „kognitív”, azután pedig az intelligencia-kutatásokra támaszkodó információelméletek és elmélettársulások következnek. Nem állítom, hogy másként nem lehet tipologizálni, de a szóban forgó témák egy tudomány- és ismeretelméleti osztályozási kísérlettel nagyjából az említett tudományelméleti csomópontok köré csoportosíthatók. (5. ábra)

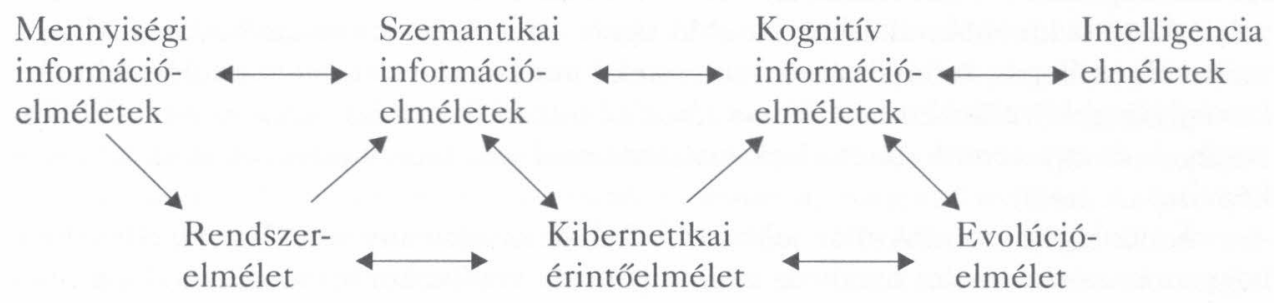

5. ábra. Az információtudomány fejlôdése az ezredfordulón, az érintố- és társelméletekkel együtt

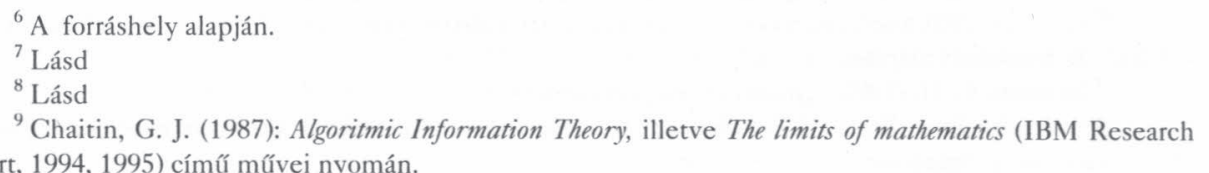
Report, 1994, 1995) címú múvei nyomán. 
A mennyiségi vagy „reál” információelméletek jellegzetes vonulatai között említhetố a gráfelmélet (amely a messzi múltból indulva, 1736-tól építette fel magát), az algoritmusos információelmélet (AIT), amely a shannoni információelmélet és a turingi számításelmélet (Turing, 1936, Chaitin, 1996) ${ }^{10}$ érintôzése - ezek olyan kurzusok tananyagaiként jelennek meg, amelyekben az információelmélet az entrópiával és a statisztikai komplexitás elméletével együtt szerepel.

A ma talán legszélesebb vonulatot az egyesített fizikai (információ)elmélet képviseli, ami magában foglalja a húrelméletet, az alkalmazott téridófizikát (Harmuth, 1993), ${ }^{11}$ valamint a kvantuminformáció-elméletet és a kvantumszámítás-elméletet, összefoglaló kifejezéssel: a kvantuminformáció-tudományt. A húr- vagy szuperhúrelméleten több mint 300 fizikus dolgozik világszerte. Az információtudománynak és a jövốnek elkötelezett szakértôket reprezentatív találkozóikon mindig újabb és újabb lökésszerû tudományos impulzusok érik (lásd , 2004). ${ }^{12}$ A téridőfizikában az információelmélet lehetôségei abban nyilvánulnak meg, hogy a tér-idő kontinuum megfigyelhetôségének problémáját a korábbi sejtésszintû́ minôsítésekról a mai kutatások kísérletileg igazolt tényeire, a tudományos intézményesülés alapjaira redukálják. A kvantuminformációtudomány azt az egyre táguló tudományos világegyetemet próbálja kezelhetôvé tenni, ami a „klasszikus” információ és a „kvantuminformáció” fogalmai között helyezkedik el. ${ }^{13}$ A kvantuminformáció és a kvantumszámítógép kísérleti szinten már realitások, és az áttörés a levegóben van, ahogy például a teleportálási kísérletek lehetôsége is (Bennett, 1993, Shor, 1994). ${ }^{14}$ A kvantuminformáció-tudomány elméleti és oktatási szintủ intézményesülése eloórehaladott fázisba került, amint azt a CALTECH kvantuminformációs intézetének kutatásai (lásd ), valamint a és a forráshelyeken folyó viták tanúsítják.

Megint más a biológiai információelméleti kutatások világa, ahol eleinte az általános információelmélet biológiai vonatkozásainak felismerése és tudatosítása volt a fő esemény. Ezután a kutatás és fejlesztés kiterjeszkedett a biokémiai molekulagépek, a biomolekuláris számítógépek, a molekulaszerkezetek és a funkciók számítógépes modellezései, a vonatkozó adatbázisok építése, a nanotechnológia, valamint a makro- és mikroszkópikus termodinamika területeire. A klasszikus információ és a kvantuminformáció közötti korábbi váltáshoz hasonló ugrás a biológiai információtudományban a mesterséges élet és az önszervezó rendszerek kutatásával, valamint az evolúcióelmélet kibomlásával következett be. Ezen a téren az intézményesülés olyan ismert tudósközösségek és egyetemi kutatóhelyek kialakulásával járt, mint amilyeneket pl. a fórum képvisel.

Különleges konjunktúrát jelez az információtudomány elméleti fejlődésében, hogy az evolúcióelmélet hatalmas vitákat generál, amelyeket jól reprezentál a terület

\footnotetext{
${ }^{10}$ Lásd Turing, A. M. (1936): On computable numbers, with an application to the Entscheidungsproblem (Proc. Lond. Math. Soc. ser. 2., 42., 43.) címú alapmúvét.

${ }^{11}$ Harmuth, H. F. (1993): Information Theory Applied to Space-Time Physics. 320.

${ }^{12}$ A String'2001 konferencia dokumentumai a strings@theory.tifr.res.in forráshelyen találhatók.

${ }^{13}$ A forráshely alapján.

${ }^{14}$ Bennett, C. H. (1993): Quantum teleportation.

(); valamint Shor, W. P. (1995) „Scheme for reducing decoherence in quantum memory” (Phys. Rev. A 52) címú múvei nyomán.
} 
szakértóinek az evolúciós folyamatokról, illetve a mutációk kódolásának megértését keresô információelméletról Richard Dawkinsszal folytatott disputája. ${ }^{15} \mathrm{~A}$, miként jön létre a szükséges információtartalom a DNS-ben?” kérdésre adott válaszok nagyjából a következő, anekdotikus összegezéshez vezettek: „Feltettük a kérdéseket. De Isten nem válaszolt!" Ebból látható, hogy Dawkins kihívta maga ellen a sorsot, amikor sajátos evolutív információs relativitáselméletével magára szabadította a biológia és a biokémia szaktekintélyeit. A biológusok szerint ugyanis a DNS információtartalmának a humán géntérkép elkészülte után is alig 15-20\%-át, a hetvenezer humán gén közül alig ötezernek a múködését ismerjük. Mindazonáltal az evolúció információelméletének vitáiban már egészen elképesztô feltevések születnek, és valaminek történnie kell a közeljövóben.

A mennyiségi-matematikai-fizikai (vagy „reál”) és az evolutív biológiai információelméletek között markáns vonulatot képeznek a rendszerelméletek, és velük mély transzdiszciplináris érintốlméleti kapcsolatban a kibernetika. A tartalom (anyag) + struktúra = rendszer, vagy a tartalom $($ dolog $)$ + struktúra = káosz típusú információstruktúrák a rendszerelmélet terén - nem véletlenül - egy másik tudomány, a biológia felól közeledő tudósban (Bertalanffy, 1936) találtak olyan gondolkodóra, aki felismerte a tudományterületek egységesülésének szükségességét. A korai rendszerelmélet és a mai rendszerszemlélet fejlődésmenetében a „rendszer” állandó elemei (input, output, process, feedback, control, environment, goal) és az információ között fennálló kölcsönös viszony újabb és újabb korszakai következtek egymásra. A rapaporti definíció (1991) szerinti rendszer (olyan entitás, mely fenntartja a szervezetet a belsố és külsố változások ellenében) és a ryani definíció (1994) szerinti rendszer (elemek és tárgyak egy bizonyos cél elérésére irányuló interakciója) fogalomkészletének átalakulása a statikus és a dinamikus információelméleti rendszerszemlélet fejlődésmenetében is új, sajátos irányokat hozott. A rendszerelmélettel érintkezó információelméletek közül itt csak néhány érdekes társulás, például az autozófia (Holtz, 1974), a térinformáció, az információs építészet, valamint a katonai információelmélet (vagy információháború-elmélet) sajátosságaira mutatok rá. Az autozófia az öntanító és önszervezô struktúrák elmélete (ilyen alapon a tanuláselméleteket gyújtő ágba sorolhatnánk, de jó okkal hivatkozhatunk rá itt is), amely Klaus Holtz Autosopher nevú szabadalmában testesül meg. Itt az információ- és adatfeldolgozást segítô gépról van szó, amely a Memexhez hasonló funkciót tölt be: ez a betanítható „fekete doboz” szerkezet a hagyományos beléptetố programozás nélkül múködik, viszont egy Content Addressable Read Only Memory (CAROM) egységgel van felszerelve. A földrajzi információs rendszerrel intézményesült térinformáció-elméletre nem térhetek ki részletesebben, bár ennek is vannak új, meglepó nyitásai. Az információs építészet (information habitat) elmélete az „információs környezet” és az információtudatos viselkedés ötvözeteként kap hivatkozási teret. A katonai információelmélet az információháború mibenlétét van hivatva rendszerbe foglalni: egyfelól az információtechnológia felhasználási lehetôségeit, másfelól pedig a katonai információtartalmak mobilizálásával kapcsolatos ismereteket foglalja össze. ${ }^{16}$

\footnotetext{
${ }^{15}$ A The Problem of Information for the Theory of Evolution: Has Dawkins Really Solved It? címú dokumentum nyomán, amely a () forráshelyen található.

${ }^{16}$ Holtz, K. (1978): Der selbstlernende und programmier-freie Assoziationscomputer (Elektronik Magazin) címú közleményére, továbbá a www.cosit.info, a http://habitat.igc.org és a forráshelyekre hivatkozva.
} 
A rendszerelmélet és a kibernetika kapcsolata döntô hatást gyakorolt az információtudomány fejlódésére, valamint a tudásegység formálódására is. A kibernetika információfogalma (Ashby, 1956) ${ }^{17}$ Wiener kibernetika-definíciója nyomán alakult ki „,az élố szervezetben vagy gépben történő irányítás és kommunikáció elméleteként”, amit röviden a vezérlés tudományának nyilvánítottak és egy új szemlélet megjelenését értékelték benne. Tény, hogy a kritikai rendszerszemléletú információtudomány csak azután jöhetett létre, hogy a kibernetika felépítménye megszilárdította magát a rendszerelmélet alapjain. A kibernetika egy adott gépet vizsgálva azt kérdezi, hogy „mi az összes lehetséges múvelet, amit képes elvégezni”, s azután az információelmélet felé fordul, amelynek ugyanis alapvetố jellemzốje, hogy mindig a lehetôségek egész sorozatát vizsgálja, mert „mind kiindulási adatai, mind végsố megállapításai mindig a sorozatra vonatkoznak, nem pedig egyes elemekre" (Ashby, 1956). A kibernetika kibontakozása tulajdonképpen a régi és az új tudományos világparadigma közötti váltás idejére, az 1960-as és 70-es évekre esett. A rendszerelmélet és a kibernetika találkozása és érintőelméletként való összefonódása az információelméletekkel olyan állomás a tudásegyesülés folyamatában, amely - az Ashby-féle magyarázat nyomán - a kibernetikát már olyan rendszerek vizsgálataként definiálja, amelyek energetikailag nyitottak, de az információ és a vezérlés szempontjából zártak, vagyis az információ szempontjából impermeábilisak. A rendszerelméleti rendszerszemlélet után a kibernetikai komplexitás-szemlélet hozott paradigmaváltást, s az említett entitások az információtudományban váltak még nagyobb összefüggések rendszerében magyarázott elméleti tudássá.

Áttérve a tudáselméletekre, a kognitív tudományelméletból mint az információs készségelméletek, a fizikai (kezelés-jellegû) és az intellektuális (megértés-jellegú) információs múveltség alapjaiból kell kiindulnunk. Az alapstúdiumok az információfeldolgozással kapcsolatos elméletek és a kognitív rendszer valamilyen szintú érintkezésére irányulnak (Atkinson és Shiffrin, 1968; Bransford, 1979; Craik és Lockhart, 1972; Goleman, 1995). ${ }^{18} \mathrm{Az}$ intézményesülés után felgyorsult érintőelméleti fejlődés mára olyan sok ágra bomlott, hogy itt ezeknek a felsorolására sem tudok vállalkozni. A humán és a gépi információkezelésre vonatkozóan csak hivatkozom a kognitív tudomány keretei között folyó kutatások sokszínúségére, különös tekintettel a memóriakutatásokra, valamint az alakfelismerés és a neurális hálózatok, vagy az információs interakciótervezés és az egyesített mezôelmélet szakirányaira. Mint romantikus érdekességeket kell megemlítenem például a perceptront (az 1950-es évek neurális hálózati modelljét az információészlelés és az információgyújtés teljesítmény-modellezésére, továbbá az informatront (Garfield információtárának és könyvtárának modelljét az 1960-as évekból), vagy a senstort (Ihnatowicz mobilját, az „élő múalkotást”). ${ }^{19}$

Mára a tudáselméletek is kezdenek szétágazni, mert bár az érintôelméletek szaporodásában az információelmélet nem kapott nagyobb elismerést, a társelméletek (pl. a

${ }^{17}$ Lásd Ashby, W. R. (1956): Bevezetés a kibernetikába címú, magyarul 1972-ben megjelent mûvét.

${ }^{18}$ Atkinson, R. - Shiffrin, R. (1968): Human memory: a proposed system and its control processes, továbbá Bransford, J. (1979): Human cognition: learning, understanding, and remembering, Craik, F. - Lockhart, R. (1972): Levels of processing: a framework for memory research, valamint Goleman, D. (1995): Emotional intelligence: why it can matter more than IQ for character, health, and lifelong achievement címú múveire hivatkozva.

${ }^{19}$ Lásd a http:/Chiron.valdosta.edu/whuitt/col/cogsys/infoproc.html valamint a tip.psychology.org továbbá a www.nathan.com/thoughts/unified/+theory,+information és a www.cs.toronto.edu forráshelyeket. 
kognitív pszichológia) jobb intézményesülése az adott tudományterület információelméletét is magával húzta. A tudáselméletek jelentôségét növelte továbbá, hogy a tudás gyors alkalmazásba vétele és gyenge intézményesülése (tudománnyá válásának késleltetése) esetén a mai tudáselméletek már a klasszikus információelméletek és az információtudomány egységesülésén túllépve, az információtudomány kognitív szárnyán keresztül a metaszférában is távolinak látszó intelligenciakutatás (sốt, abban is vagy száz évet elốre szaladva, az ún. Q-2 korszak) határán járnak. Ezért a tudáselméletek fogalmi, módszertani és paradigmatizáló kísérletei lényegében új dimenziót hoztak létre az információtudomány, az érintôelméletek, valamint a formális tudományterületek informális információelméletei, az információs metaelméletek világában. Összességében ez lenne az egységtudomány harmadik dimenziója, ám vannak kutatók, akik már a negyedik és az ötödik dimenzió konceptualizálásával, a modellkészítéssel, a módszertan és a paradigma kidolgozásával foglalkoznak.

A tudáselméletek új nyelvezetének megteremtésével új szellemi alapok jöttek létre, amelyek a strukturált új ismerettárak készítésének, fenntartásának és mobilizálásának gépi és intellektuális készségeit, múködtetési elveit és mechanizmusait, illetve programozását biztosítják. Az elméleti konceptualizálás során így született meg az ismerettárazás mint tudásképzés tipologizálása is a generális és/vagy specifikus, a deklaratív, a procedurális és a kondicionális tudás (ismeretképzés és raktározás, mobilizálás) leírásaként. Fontos állomás az információészlelési tartomány (kapacitás, tartam), az információtudatosság (rövid és hosszú távú memória), valamint az információ-visszakeresés (mobilizálás), továbbá a vezérlés és ellenốrzés (control process) megfogalmazása és leírása - mindezek együttesen alkotják az úgynevezett metakognitív jártasságot. A metakognitív tudás olyan (egyéni) képességeket jelent, amelyek ,a rendszeren keresztül haladó információáramlást segítố ismereteket rendezik a tanulást segítố metaelméletté”, melynek segítségével meghozható az informális-formális döntés arról, hogy az információt miként kategorizáljuk, szervezzük és interpretáljuk.

\section{Az információtudomány egyesítetł elméletéről}

Az egyesített tudáselmélet és/vagy intelligenciaelmélet koncepciója az 1980-as években a többek között J. F. Lyotard és D. Bohm elméleti munkásságával reprezentált harmadik tudáselmélettel jutott el az információ megfertốzte filozófiától a kibernetikán, az emergencia-elméleteken és a mesterséges élet elméletein keresztül a mém-elméletig (meme theory), vagy - például S. Johansen elméleti munkásságában - az informatikától az emotikáig, ahol már az anyag-energia-információ-emóció entitásokkal képzett tudásegységgel számolnak, mert „az emóció alapvetóbb és absztraktabb az információnál”. Az átváltás egy új dimenzóba az intelligenciaelméletekkel (Q-1 - Q-3) következik majd be, de ez már a „mélytudás” birodalmának távoli évszázadaiba vezet. Mindez olyan metaelmélet formájában jelenik meg, ami hivatalosan még semmilyen tekintetben nem létezik, bár az intelligenciaelmélet „tudáselméletek” cím alatt már egyetemi tananyag. A Gardner-féle multiplikatív intelligencia-felosztás az ember mint „információfogyasztó és információgyártó gép” intelligencia-alapjainak osztályozására találta ki a matematikai, logikai, nyelvi, térbeli, zenei, fizikai-kinetikus és perszoná- 
lis-interperszonális felosztásokat. Gardner szerint a kultúra lényegében a strukturált ismeret- és tudástárak legfóbb bázisaként vagy összességeként ${ }^{20}$ fogalmazódik meg.

Az így felidézett távlatok előtt azonban visszafelé is kell tájékozódni, mert az információtudomány metaelméletei most éppen „hátrafelé haladva az idóben”, a kezdeteket vizsgálva próbálják összerendezni az egységesülés számára az ismeretelméleti alapokat. Ehhez ma az információtudomány egyesített elméletével kapcsolatos kutatások adják a legjobb fogódzókat.

Az információtudomány egyesített elméletének (Hofkirschner, 1999) ${ }^{21}$ felvetését ma egy sokat idézett dialógussal, az ún. Capurro trilemmával szokás jellemezni. Ez lényegében arról szól, hogy miért nem lehet összeegyeztetni vagy közös nevezốre hozni az információ(elméletek) legkülönbözóbb megközelítéseit. Az információfogalom értelmezési lehetôségeit korábban már felvázoltuk (Csorba, 1991, 1995), ${ }^{22}$ ezért a sokféleség-összeegyeztethetetlenség típusú ellenvetések sora itt és most nem különösebben érdekes számunkra. Capurro és vitapartnereinek érvelése annyiban érdekes, hogy az egyesített elmélet logikai vezérfonala számukra a „dialektikus materializmus” helyett a „dialektikus informatizmus”, ${ }^{23}$ vagyis az ,anyag” fogalmát egyszerúen felváltják az ,információ” fogalmával. (Ami nem szentségtörés, mert az információ korában, az információs társadalomban, az információgazdaságban éppen az anyag, az energia és az információ arányainak átrendezốdése zajlik, mégpedig az információ javára, azaz minden terméknek növekszik az információtartalma, a nyersanyag- és az energiatartalom rovására.) A Capurro-féle logikai trilemma szerint az információval az a gond, hogy lehet mindig ugyanaz (univocity), lehet valami hasonló (analogy), vagy lehet valami más (equivocity). Ekkor azonban a fentiekben jelzett észlelési és értelmezési lehetőségek között határvonalat húzunk azzal, ha úgy döntünk, hogy szerintünk az információ vagy dolog, vagy jelentés (csakis az egyik, vagy a másik). Ebben az esetben nincs dilemma vagy trilemma. Ellenben a kauzalitás elve érvényes az informacionális tudományos gondolkodásban is. Az információtudomány felbukkanása tudománytörténeti paradigmaváltást jelent (egyesek szerint az információtudomány maga a paradigmaváltás), ami egyfelól számos metaelmélet ösztönzôje, másfelól a tudományegység gondolatának táplálója is lett.

\section{Összegezés helyett}

1980 és 2000 között a legfóbb kérdés az volt, hogy a tapasztalt hatalmas fejlődés nyomán képzôdött információhalmaz összeáll-e ismeretekké, azaz sikerül-e kezelhetôvé és értelmezhetốvé tenni, majd ennek nyomán egyfelól újraértelmezni eddigi tudásalapjainkat, másfelól pedig - új kérdéseket feltéve - sikerül-e új összefüggéseket feltárni egy új szemlélet jegyében. Ha ez nem sikerülne, akkor több évtizedes fejlődés után hullámvölgy következik, amit Stonier és Benz a jövő középkorának nevez. Stonier az

${ }^{20}$ Lásd Lyotard, J. F. (1984): The Postmodern Condition, valamint Bohm, D. (1985): Infolding Meaning, továbbá Johansen, S. (1985), és Garner, H. (1983): Frames of Mind címú múveit.

${ }^{21}$ Hofkirschner, W. (ed.) (1999): The Quest for a Unified Theory of Information (Proceedings of the Second International Conference on the Foundations of Information Science) címú múve nyomán.

${ }^{22}$ Csorba, J. (1991): Információ az információról =IFTI), valamint Mi az információ? (inco 2001. 2. sz.)

${ }^{23}$ A témáról bővebben lásd a www.capurro.de/trialog.htm forráshelyet. 
információ létezését végigvezeti a szubatomi szerkezetektól az emberi szellemen át a társadalom olyan termékeiig, mint a nyelv. A Stonier-féle értelmezésben az információhoz kapcsolódó „minta”, „szerkezet” és „rend” (amelynek része a káosz is) univerzális jelenség, ami - tekintet nélkül arra, hogy az ember észleli vagy sem - létezik az univerzumban. Ahogy az élet információkódja a DNS, úgy az univerzumnak is van információkódja. Stonier érvelése szerint a gépészmérnök a gôzgéppel dolgozva értette meg az inputok természetét vagy a termodinamika elveit, de az információmérnöknek ma nem áll rendelkezésére a jelenségek olyan szintû́ megértése, amit most magasabb intelligenciának (Q-1, Q-2) tekintünk. Stonier szerint az információ két fó megnyilvánulási formája a strukturális és a kinetikus forma: „az információ létezési formái azt az alapvető törvényszerúséget követik, akként léteznek, ahogy a kontextus vagy a struktúra, vagyis az információforma megjelenik vagy eltúnik, aszerint, hogy a struktúra látható-e vagy sem".

A Stonier munkásságára tett kitérő segítségével modellezhetjük azt a fejlődést, amelynek a végén az egységesülő elmélet eljut annak a felismeréséig, hogy az intelligencia a fejlett információfeldolgozó rendszerek (IFR-ek) evolúciójának a terméke. „Az intelligencia állapotot vagy körülményt jelent, amit a rendszer viselkedésében (vagy dinamikájában) lehet észlelni: alapállapotai a túlélés, a reproduktivitás, a célba érés képessége és a tanulás." A tudat információhierarchiákból áll, amelyeket az információ-, adat-, ismeret- és tudásstruktúrák alkotnak, s ebben a stonieri gondolatmenetben az információ rendezett adatot jelent.

Sajátos nyitást jelent ebból a szemléletrendszerból az emergencia-koncepció, illetve az anyag és az információ egységét hirdetô (pontosabban az információt az anyag egy sajátos állapotának tekintô) megközelítés. Az emergenciaelmélet foglalkozik olyan anyagi rendszerekkel, amelyek informacionális kvalitásokat mutatnak fel és olyanokkal is, amelyek nem, de azt is feltételezi, hogy nincs olyan információgeneráló vagy információfeldolgozó rendszer, amelynek ne lennének anyagi alapjai.

Végül az információ- és tudáselméletek egyesített információtudománya ma olyan nagyelmélet-törekvésekkel is építi magát, mint az egyesített természet elmélete: a „Grand Unified Theory”, a „Final Theory” (lásd ) vagy a „Theory of Everything”. A ,végsó elméletet” reprezentáló kötet tulajdonképpen egy Fukuyama-analógia, , , a hivatalos tudomány végét" hirdetố könyv lett, leszámolás a tudomány múltjával, jelenével és tegnapi jövójével is.

\section{A metaelméletek információelméleti horizontjairól}

Az információtudomány-elmélet - metaelméleteivel együtt - már olyan világ, ami „odaát van”. Vannak természetesen elôzményei, amelyek az információtudomány ismeretelméleti disputáiban mindennapi eseményeknek túnnek, és van jelene is. Vannak továbbá olyan fontos új felismerései is, mint pl. a Vickery-elv, miszerint nincs metaelmélet információelmélet nélkül (Vickery, 1997). ${ }^{24}$ Számos információelméleti enciklopédista dolgozik az eddigi kutatások és elmélettöredékek rendszerbe (egység-

\footnotetext{
${ }^{24}$ Lásd Vickery, B. (1997): Metatheory and information sicence. J. Of Documentation, 53 (5).
} 
be) foglalásán, illetve az eddigi fejlemények dokumentálásán. Mindent összevéve, fontos látnunk és értenünk azt a fejleményt, hogy az információ elméleti, metaelméleti és filozófiai értelmezéseiben elkülönül egymástól egy fizikai és egy szellemi paradigma. A fizikai paradigma szerint az információ észlelése és visszakeresése objektív, semleges folyamat, amelyben a megoldás technológiai jellegú, s ennélfogva a tudásképzésról sok minden megtanulható. A szellemi paradigma szerint viszont az ismeretek tudássá és intelligenciává (magasabb és még magasabb rendú tudásokká) szervezése ismeretelméleti és (egyéni) tartalmi tudást igényel, ami nem annyira tanítható. (Ez esetben is érvényesül az erős gyakorlati vagy piaci tudás és a gyengén intézményesülő elméleti tudás dichotómiája.)

A meta-metaelméletek terepén az információtudomány felól közeledve elôször az információ értelmezésében kellett közös nevezốre jutni, amit a különféle szemléletek vagy megközelítések - az információ mint dolog (adat, dokumentum), az információ mint ismeret (a strukturált információ), valamint az információ mint folyamat (az információ birtoklása, a tájékozottá válás) - intézményesülése meg is oldott (Buckland, 1991). Másodszor a nyelvezet-alapú, a módszertani típusú és a rendszer-jellegú modellezés alapjainak kialakulása volt soron: ezeknek a megoldottságát az internet, pontosabban a web metarendszer-, metaprogram-és metanyelv-jellegével szokás reprezentálni.

A gyakorlati (vagy piaci) metaelméleti jelen a humán metaadat-termelésben testesül meg leginkább, aminek jelentôs része automatizált, gépi eljárás: a folyamat-, tárgyvagy tartalom-keresés folyamatában a számítógép már automatikusan generál jelzó-indexelő utalásokat, gépi kezelókódokat. Mindezt csak azért említjük, mert az emberi információtermelés a metaadatok mint kezelókészségek állandó, folyamatos termelésével jár együtt, s ennek alkalmazott tudományos elméletei már több évtizedes intézményesülés hátterével rendelkeznek a deskriptív, a strukturális és az adminisztratív metaadat-használat terén. A web metaadat-tartalma számunkra igazán a Grid metaadattartalmának elérése és megértése kapcsán vált érdekessé, különös tekintettel a szemantikus Gridre (lásd ), ami a W3C Semantic Webre () épül. ${ }^{25}$

A web látható (statikus) és láthatatlan (dinamikus) tartományainak együttes múködése olyan metarendszerekben megy végbe, amelyek kevesek számára nyújtanak egyformán ismerôs és érthetố információt, s az információkezelési múveltség terén fennálló szintkülönbségek jelentősen megosztják az emberi társadalmat. A statikus weboldalakat bárki elérheti, azonban a dinamikus weboldalak (amelyeket a számítógép generál a felhasználó és az információ szolgáltatója közötti közvetítés biztosításához) csak kevesek számára érhetók el, s ez a különbség nem pusztán információtechnológiai kérdés, hanem az információtartalom tekintetében, vagyis az ismeretek, a tudás, illetve az intelligencia terén is számottevô hiányt vagy többletet jelent. A statikus weboldalak csupán generikus információszolgáltatásával szemben a dinamikus weboldalak egyedi és specifikus információt nyújtanak, ami olyan hatalmas különbség, mint a televíziós médiumban az igen alacsony információtartalmú tömegmúsorok és a magas információtartalmú, de csak szúk közönségnek szóló rétegmúsorok közötti eltérés.

${ }^{25}$ Lásd De Roure, D. - Jennings, N. - Shadbolt, N. (2003): The Semantic Grid: A Future e-Science Infrastructure. In: Berman, F. et al. (eds.): Making the Global Infrastructure a Reality. (www.grid2002.org). 


\section{A tudomány metainformációs piramisáról}

Ezen a téren már könyvtárnyi irodalom gyúlt össze, ám még mindig nem elég nyilvánvaló, hogy a szemantikus web mit tesz hozzá a tudományhoz. Csak az információtudományos fejlődés mutatott rá, hogy a tudomány és az információ viszonya egy metainformációs rendszer logikája alapján múködik. Ennek a viszonyrendszernek az egyik felülvezérelt tulajdonsága az, hogy minden komplex rendszer informacionális entitás. E gondolatmenet szerint a tudomány információpiramisát az egyik oldalon a tudományos auktorok (a tudósok, kutatók és innovátorok), a másik oldalon pedig a tudományos struktúrák (az intézményrendszer összetevoói) építik fel. A piramis alsó szintje arra a törvényszerúségre épül, hogy a tudomány információt generál az információs rendszerek alapján. A középsố szintet az a törvényszerúség határozza meg, hogy a tudomány maga is másodfeldolgozó információs rendszer, ami metainformációt hoz létre. A piramis felsố része vagy csúcsa pedig arra a törvényszerúségre támaszkodik, hogy a tudományfilozófia (a tudomány tudománya) harmadfeldolgozó készségei révéti információt generál az információra vonatkozó információról.

A tudományos információ, ismeret és tudás az indukció és a dedukció, az absztrakció és a konkretizáció olyan kettôs folyamataként is leírható, amelyben a tudományos ismeret egyszerre jelent elméleti és empirikus tudást, s ezek olyan hurokba rendezôdhetnek, ami két önszervezô folyamatból tevődik össze. Evidens, hogy a tudományos ismeret önszerveződése kölcsönösen produktív viszonyt jelent a tapasztalat és az elmélet között: a tudományos ismeret a tapasztalat és az elmélet egysége. A tudományos ismeretek formálódásának információtudományos szemlélete, az információtudatosság szerint a tudományos ismeret önszervezôdése olyan dialektikus ciklusnak felel meg, amelyben az anyagi valóság jelei experimentális adatokká válnak, amelyeket azután hipotézisekben és elméletekben interpretálunk, hogy azután módszerekké, eljárásokká és technológiákká transzformálhassuk óket, amelyeknek a hatásai megjelennek és tovagyưrúzódnek az anyagi valóságban, amit azután ismét megfigyelhetünk és adatokban rögzíthetünk, és így tovább (Fuchs, 1999). ${ }^{26}$

\section{A szövegben előforduló egyéb utalások forrásai}

Buckland, M.(1991): Information as Thing. J. of the American Society for Information Science, 42. k. 5. sz., 351-360.

Bush, V. (1945): As We May Think. The Atlantic Monthly, (July 1945).

Castells, M. (1996): The Rise of the Network Society. The Information Age: Economy, Society and Culture. Volume 1. Blackwell, Oxford. Magyarul: A hálózati társadalom kialakulása. Gondolat, Budapest, 2005.

Fodor, J. (1987): Psychosemantics.

Gardner, H. (1993): Frames of Mind. The theory of multiple intelligences.

Lakatos, I. (1970): Criticism and the Growth of Knowledge.

Langer, S. (1942): Philosophy of a New Key.

${ }^{26}$ Fuchs, C. (1999): Science as a Self-Organizing Meta-Information System () címú múve alapján. 
McLuhan, M. (1972): Take Today: The Executive as Dropout.

Mannheim, K. (1952): Essay on the Sociology of Knowledge.

Masterman, M. (1970): The nature of paradigm. In: Lakatos-Musgrave (eds.): Criticism and the Growth of Knowledge.

More, M. (1998): The Extropian Principles. V.3,0.

Rapaport, W. (ed.) (1991): Cognitive Science Technical Report.

Simon, H. A. (1979): Models of Thought.

Smith, J. A. (1991): The Idea Brokers: Think Tanks and the Rise of the New Policy Elite.

Stonier, T. (1990): Information and the Internal Structure of the Universe.

Stonier, T. (1992) Beyond Information. The Natural History of Intelligence.

Stonier, T. (1997) Information and Meaning. An Evolutionary Perspective. 